\title{
Perancangan Chassis Traktor Angkut Hasil Pertanian
}

\author{
Mohammad Maulfi Haris Fanani dan Julendra Bambang Ariatedja \\ Departemen Teknik Mesin, Institut Teknologi Sepuluh Nopember (ITS) \\ Corresponding Author: ariatedja@me.its.ac.id
}

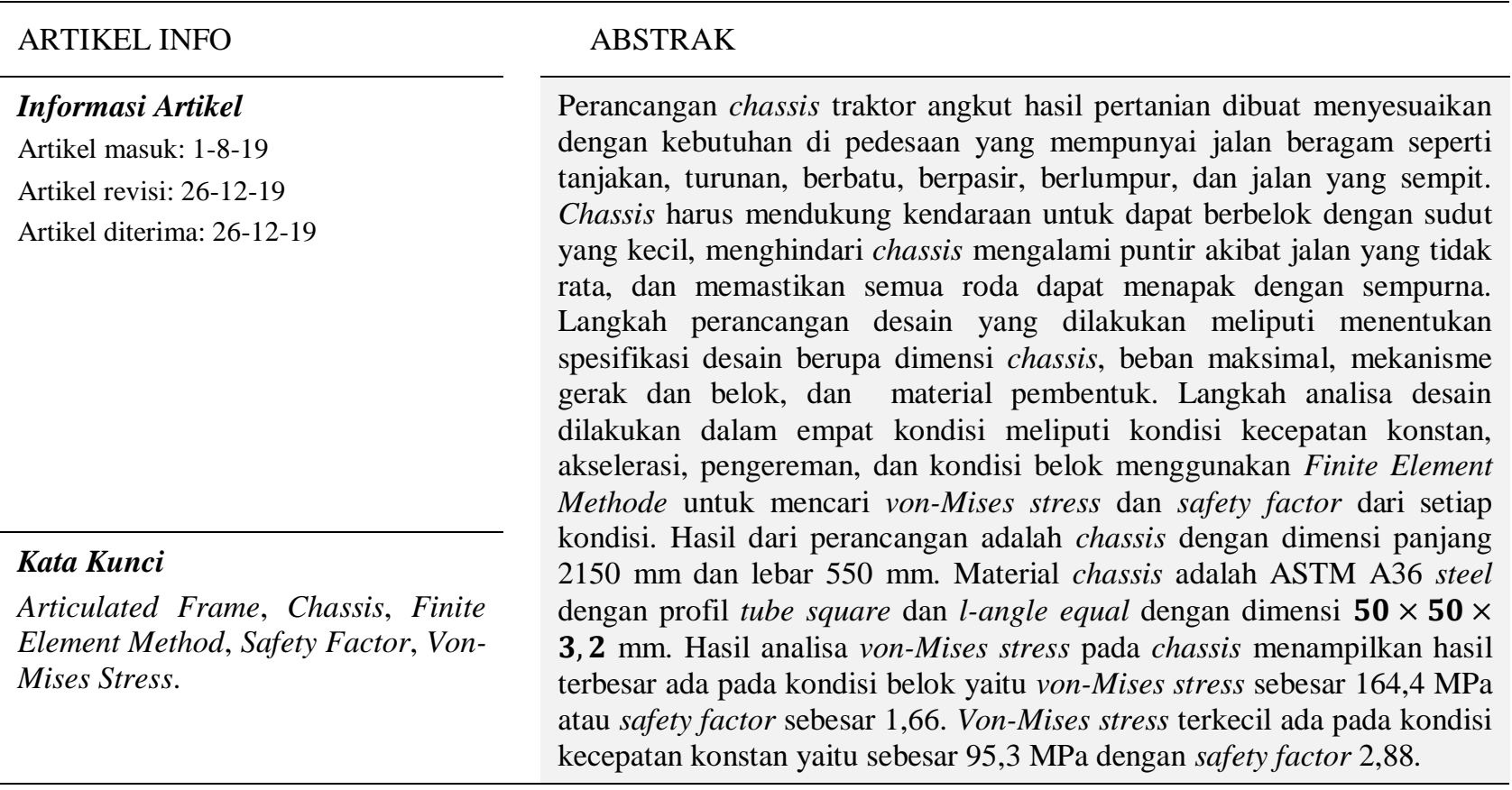

\section{PENDAHULUAN}

Pertanian merupakan sektor yang memiliki peranan penting bagi perekonomian di Indonesia yang salah satunya ditunjang oleh adanya alat angkut hasil pertanian. Alat angkut hasil pertanian yang digunakan saat ini terdiri dari alat angkut tradisional hingga alat angkut modern. Sebenarnya banyak dijual alat angkut khusus hasil pertanian, namun masyarakat pedesaan masih belum menggunakannya karena dirasa mahal serta suku cadang yang sulit ditemukan di pedesaan. Untuk memenuhi kebutuhan, maka petani merakit sendiri sebuah alat angkut yang dibuat tanpa perhitungan dan analisa yang benar sehingga dapat membahayakan keselamatan penggunanya.

Solusi dari permasalahan tersebut yaitu alat angkut hasil pertanian yang sesuai dengan kebutuhan, harganya terjangkau, aman digunakan. Penelitian sebelumnya yang dilakukan oleh Rahim, F. N. pada tahun 2018 [1], tentang perancangan dan analisis sistem transmisi infrastructural mobile dari hasil pertanian. Hasil dari penelitian tersebut yaitu mesin dan transmisi yang digunakan untuk traktor angkut hasil pertanian. Sehingga perlu dilakukan penelitian lanjutan tentang perancangan dan analisa chassis traktor angkut hasil pertanian untuk melengkapi penelitian yang telah dilakukan.

Tujuan penelitian ini adalah menentukan spesifikasi dari profil, material, dan dimensi chassis traktor angkut hasil pertanian yang. Kedua yaitu mengetahui gaya reaksi yang bekerja pada chassis traktor angkut hasil pertanian dan terakhir yaitu menampilkan hasil analisa dengan simulasi pada rancangan chassis traktor angkut hasil pertanian.

\section{METODE PENELITIAN}

\section{A. Diagram Alir}

Diagram alir perancangan chassis traktor angkut hasil pertanian ini dapat dilihat pada Gambar 1 .

\section{B. Spesifikasi Desain}

Berikut ini merupakan spesifikasi yang ditentukan dalam perancangan chassis traktor angkut hasil pertanian :

\section{1) Dimensi}

Dimensi chassis disesuaikan dengan jalan di pedesaan. Berdasarkan pengamatan langsung di lapangan, didapatkan lebar jalan di daerah pedesaan memiliki lebar berkisar antara 1,5 hingga 2,0 meter. Sehingga, lebar maksimal traktor angkut hasil pertanian yaitu tidak lebih dari 1,1 meter.

\section{2) Kapasitas Beban}

Beban yang diterima chassis selain massa dari chassis itu sendiri terdiri dari 3 beban yaitu : mesin dan sistem transmisi, pengemudi, dan muatan. Massa dari mesin dan transmisi maksimal $145 \mathrm{~kg}$. Massa maksimal dari pengemudi dibatasi yaitu maksimal $100 \mathrm{~kg}$. Massa dari muatan berdasarkan mesin dan transmisi yang telah dirancang sebelumnya yaitu sebesar $500 \mathrm{~kg}$.

\section{3) Mekanisme Gerak dan Belok}

Traktor angkut hasil pertanian didesain mempunyai empat roda dimana roda depan sebagai penggerak dan sekaligus sebagai penentu arah gerakan belok. Sistem steering traktor angkut hasil pertanian berbelok dengan menghambat putaran salah satu roda depan sehingga dengan adanya differensial, roda pada sisi satunya akan bergerak lebih cepat sehingga kendaraan dapat berbelok. 


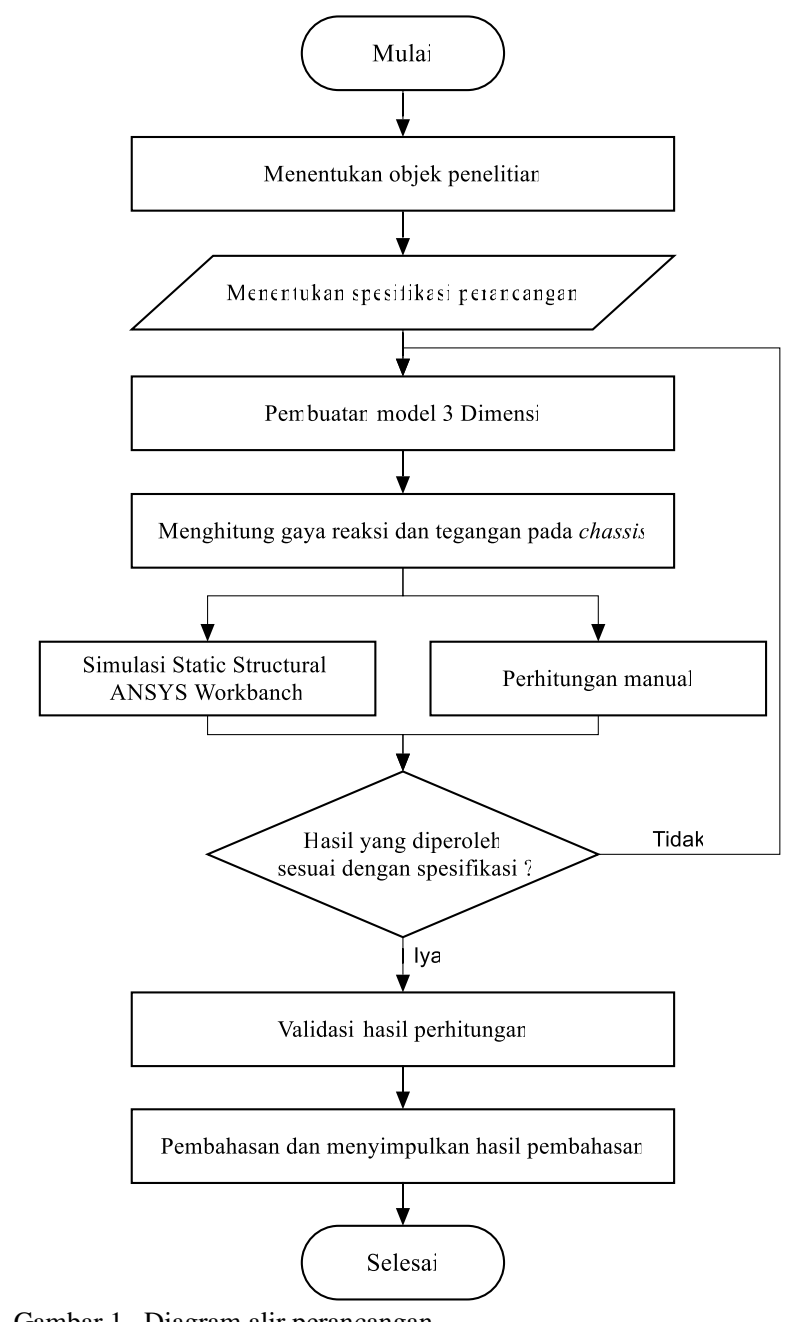

Gambar 1. Diagram alir perancangan.

\section{4) Bentuk Chassis}

Chassis dibuat fleksibel agar chassis bagian belakang dapat mengikuti arah belok dari chassis di bagian depan. Bentuk dari chassis ini dikenal dengan nama Articulated Frame [2]. Bentuk chassis ini memiliki kelebihan yaitu radius putar kendaraan menjadi sangat kecil.

5) Material Chassis

Material yang digunakan untuk chassis adalah ASTM A36 steel dijual umum di pasaran. Material ASTM A36 steel memiliki sifat sebagai berikut :

\begin{tabular}{lcc}
\multicolumn{3}{c}{ Tabel 1. Sifat material ASTM A36 steel. } \\
\hline \multicolumn{1}{c}{ Property } & Value & Units \\
\hline Elastic Modulus & $2,1 \times 10^{11}$ & $\mathrm{~N} / \mathrm{m}^{2}$ \\
Poison's Ratio & 0,28 & $\mathrm{~N} / \mathrm{A}$ \\
Mass Density & 7800 & $\mathrm{~kg} / \mathrm{m}^{3}$ \\
Tensile Strength & $4,1 \times 10^{6}$ & $\mathrm{~N} / \mathrm{m}^{2}$ \\
Yield Strength & $2,75 \times 10^{6}$ & $\mathrm{~N} / \mathrm{m}^{2}$ \\
\hline \hline
\end{tabular}

\section{Langkah Perancangan Chassis}

Pemodelan dilakukan untuk menerjemahkan spesifikasi desain yang ada ke dalam sebuah model 3 dimensi, sehingga dapat dilakukan proses perhitungan dan analisa. Pemodelan dilakukan dalam beberapa tahap hingga menemukan geometri yang sesuai dengan spesifikasi yang telah di tentukan.

\section{1) Membuat Model Chassis Ladder Frame.}

Pertama kali yang dilakukan ketika merancang chassis traktor angkut hasil pertanian yaitu membuat sebuah bentuk rangka ladder frame.

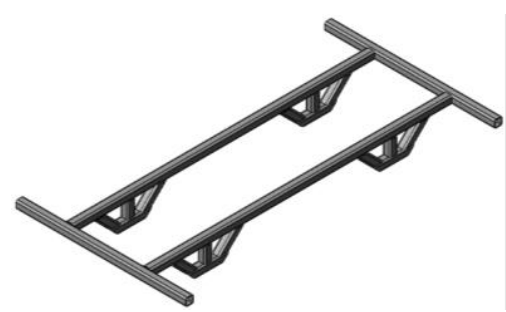

Gambar 2. Model chassis ladder frame.

\section{2) Membuat Model Chassis Articulated Frame}

Chassis dipisah menjadi dua bagian agar kendaraan dapat berbelok. Chassis bagian depan menentukan arah belok kendaraan, sedangkan bagian belakang mengikuti pergerakan bagian depan.
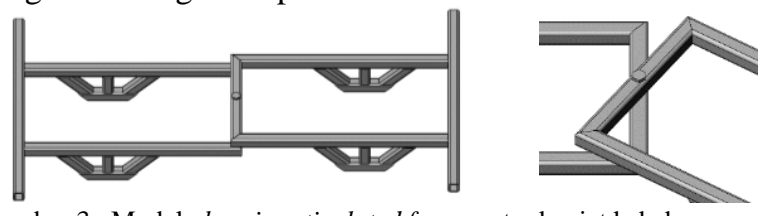

Gambar 3. Model chassis articulated frame satu derajat kebebasan.

Jalanan di pedesaan tidak hanya sempit tetapi memiliki kontur yang tidak rata sehingga chassis menjadi rawan bending karena tidak semua roda menapak pada permukaan ketika jalan yang tidak rata. Chassis ditambah satu bagian lagi yang berfungsi menghilangkan bending.

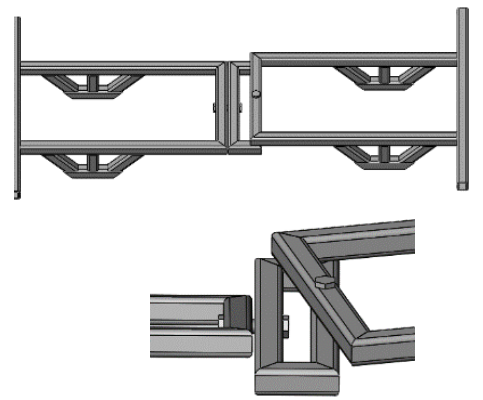

Gambar 4. Model chassis articulated frame dua derajat kebebasan.

3) Membuat Dudukan Beban pada Chassis

Tahapan selanjutnya adalah membuat dudukan untuk beban pada chassis untuk mesin dan transmisi, pengemudi, dan muatan.
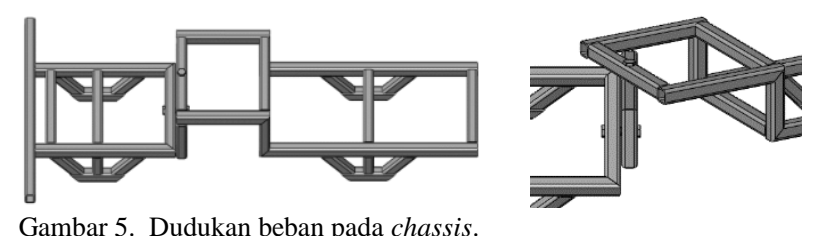

Gambar 5. Dudukan beban pada chassis.

\section{4) Menyempurnakan Model Chassis.}

Perhitungan yang dilakukan pada chassis menghasilkan letak bagian - bagian kritis pada chassis sehingga kritis itu diperbaiki dan diperkuat menjadi sebuah desain baru.

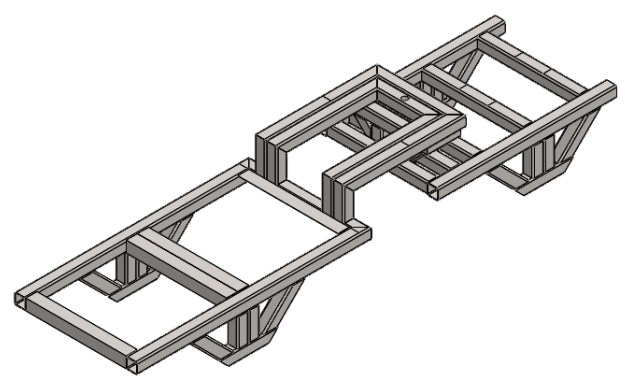

Gambar 6. Model chassis hasil penyempurnaan. 


\section{Langkah Analisa Chassis}

Analisa dilakukan menggunakan Finite Element Methode untuk mengetahui bagian kritis dari chassis dengan analisa von-Mises stress untuk mencari safety factor. Analisa dilakukan dalam keadaan statis. Beban dikalikan faktor dinamis sebesar 3 untuk mewakili keadaan sebenarnya. Tahapan analisa menggunakan FEM sebagai berikut :

1. Memindahkan model 3 dimensi ke software finite element.

2. Menggunakan Static Structural untuk menganalisis struktur dalam keadaan statis.

3. Memasukkan data material dari model ke dalam Engineering Data.

4. Membuka halaman Mechanichal dimana merupakan tempat untuk dapat melakukan proses analisa.

5. Mengaplikasikan data material dari Engineering Data ke dalam masing - masing bagian dari chassis.

6. Mendefinisikan sambungan antar struktur chassis.

7. Mendefinisikan joint antar bagian chassis.

8. Melakukan proses meshing yaitu proses membagi bagian dari model yang di analisa menjadi bagian bagian yang lebih kecil.

9. Mengaplikasikan parameter pada chassis berupa gaya - gaya yang terjadi, momen, dan percepatan gravitasi.

10. Mendefinisikan titik tumpu pada chassis dimana ada pada setiap roda.

11. Menampilkan tegangan von-Mises stress dan safety factor.

\section{E. Massa Chassis}

Massa chassis didapatkan dari mengalikan volume material dengan berat jenis material. Material chassis adalah ASTM A36 steel dengan profil tube square dan $l$ angle equal dengan dimensi $50 \times 50 \times 3,2$.

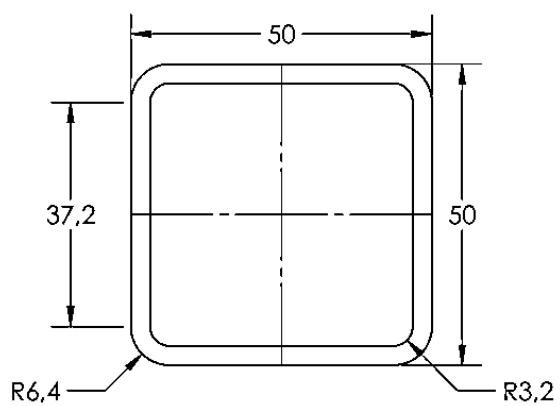

Gambar 7. Profil tube rectangular.

Luas penampang profil tube square:

$4 \times 37,2 \times 3,2+\frac{22}{7}\left(6,4^{2}-3,2^{2}\right)=572,7 \mathrm{~mm}^{2}$

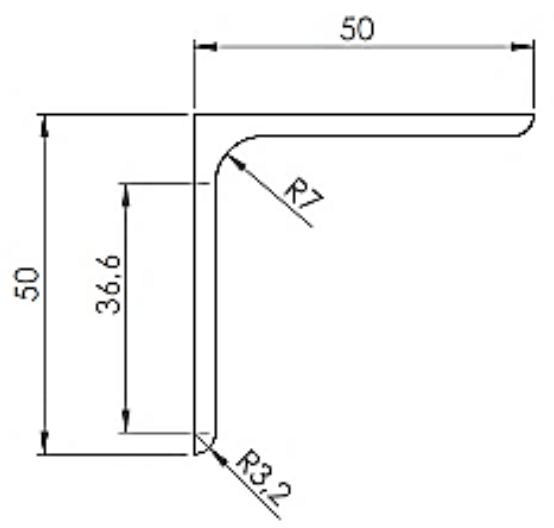

Gambar 8. Profil l-angle equal.
Luas penampang profil $l$ angle equal :

$$
\begin{aligned}
2 \times 36,6 \times 3,2+ & \frac{22}{7 \times 2}\left(3,2^{2}\right)+7^{2}-\frac{22}{7 \times 4}\left(3,7^{2}\right) \\
& =315,9 \mathrm{~mm}^{2}
\end{aligned}
$$
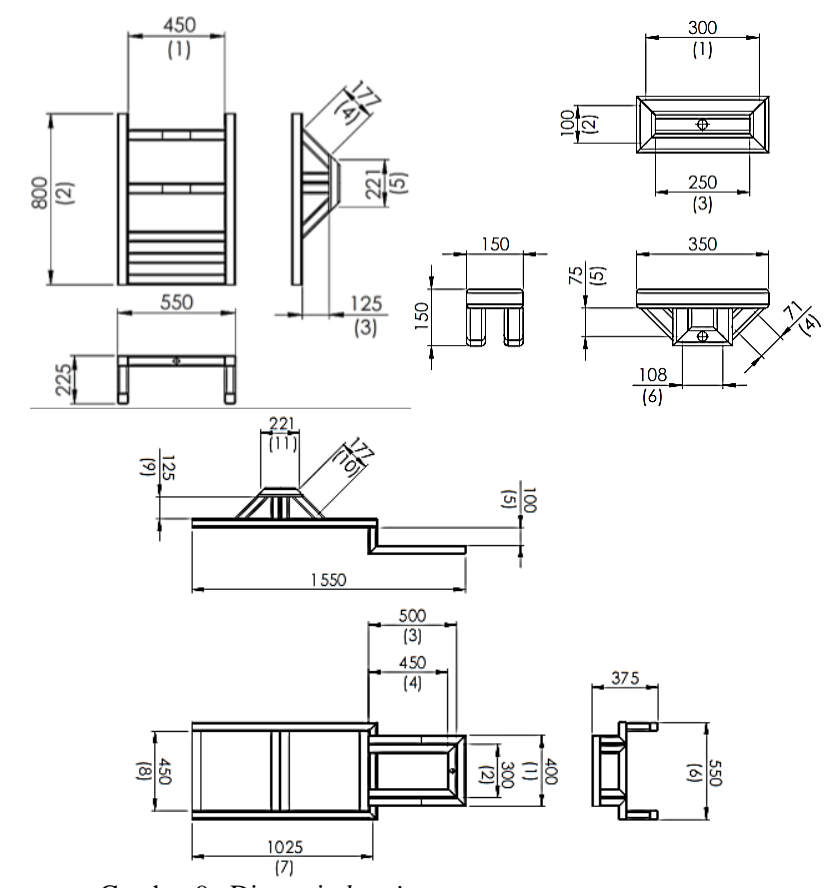

$\frac{108}{(6)}$

Gambar 9. Dimensi chassis.

Tabel 2. Berat beban yang diterima chassis.

\begin{tabular}{|l|r|}
\hline \multicolumn{1}{|c|}{ Bagian } & $\mathrm{m}(\mathrm{kg})$ \\
\hline Depan & 24,8 \\
\hline Tengah & 8,5 \\
\hline Belakang & 36,7 \\
\hline & 70,0 \\
\cline { 2 - 2 }
\end{tabular}

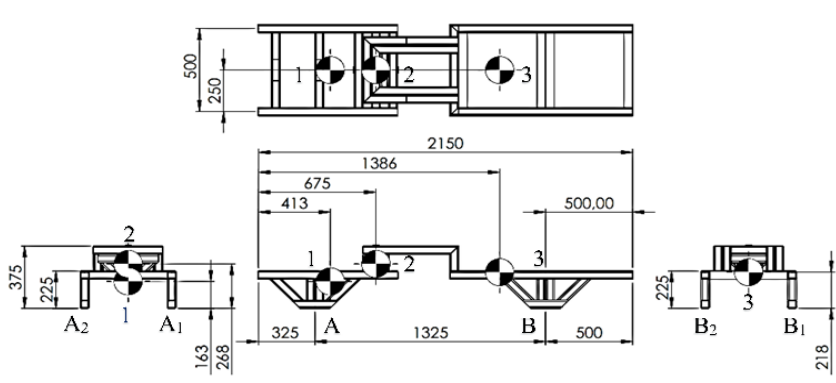

Gambar 10. Titik berat setiap bagian chassis.

\section{Beban pada Chassis}

Beban pada chassis terdiri dari 3 jenis yaitu mesin beserta sistem transmisi, pengemudi, dan muatan. Berat masing - masing dari beban ada pada Tabel 3.

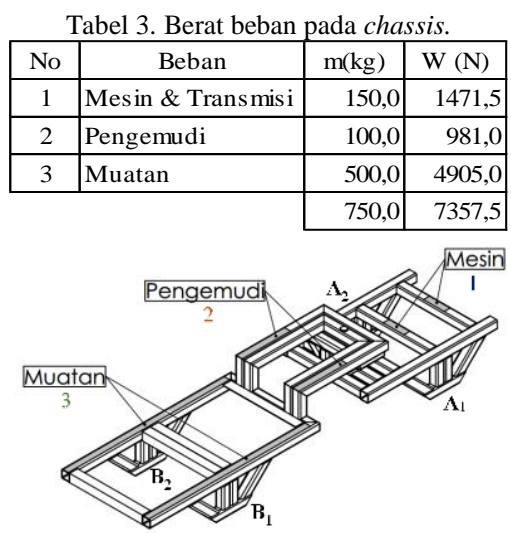

Gambar 11. Lokasi beban pada chassis. 


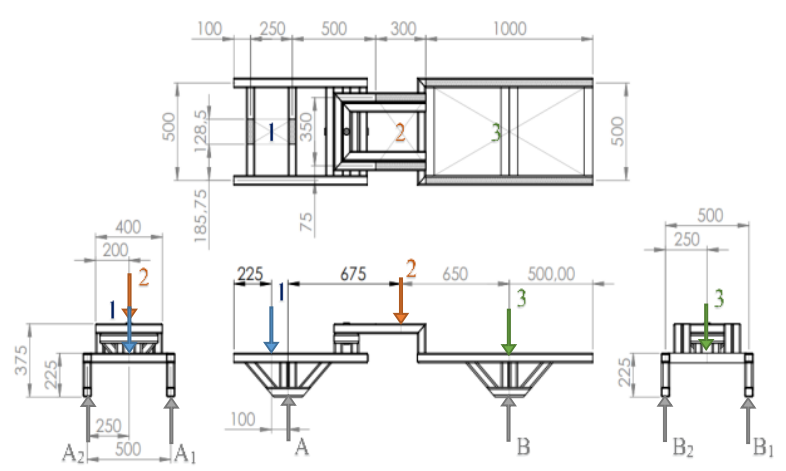

Gambar 12. Lokasi pembebanan pada chassis.

Keterangan :

A = Reaksi tumpuan bagian depan

$\mathrm{B}=$ Reaksi tumpuan bagian belakang

$1=$ Beban Mesin dan Transmisi

$2=$ Beban Pengemudi

3= Beban Muatan

\section{HASIL DAN PEMBAHASAN}

\section{A. Analisa Kekuatan Chassis}

Analisa kekuatan pada chassis meliputi perhitungan beban vertikal, beban akibat akselerasi, beban akibat pengereman, dan beban akibat belok.

\section{Kondisi Bergerak Lurus Konstan}

Kondisi pertama adalah ketika kendaraan melaju lurus dengan kecepatan konstan. Beban yang diterima saat melaju dengan kecepatan konstan adalah beban vertikal. Beban vertikal dipengaruhi oleh massa - massa dari komponen kendaraan yang bertumpu pada chassis. Beban vertikal akan digunakan pada simulasi adalah beban dinamis. Untuk perhitungan desain, beban dinamis yang terjadi pada kendaraan ketika melaju pada kondisi sebenarnya dapat diganti dengan pembebanan statis dikalikan dengan faktor beban dinamis yang besarnya 3 . [3].

$$
\mathrm{F}_{\mathrm{d}}=\mathrm{k} \cdot \mathrm{F}_{\mathrm{s}}
$$

Tabel 4. Berat beban yang diterima chassis.

\begin{tabular}{|l|r|r|r|}
\hline \multicolumn{1}{|c|}{ Beban } & \multicolumn{1}{c|}{$\mathrm{m}(\mathrm{kg})$} & \multicolumn{1}{c|}{$\mathrm{W}(\mathrm{N})$} & $\mathrm{W}_{\text {dinamis }}(\mathrm{N})$ \\
\hline Mesin \& Transmisi & 150,0 & 1471,5 & 4414,5 \\
\hline Pengemudi & 100,0 & 981,0 & 2943,0 \\
\hline Muatan & 500,0 & 4905,0 & 14715,0 \\
\hline \multirow{2}{*}{} & 750,0 & 7357,5 & 22072,5 \\
\cline { 2 - 4 }
\end{tabular}

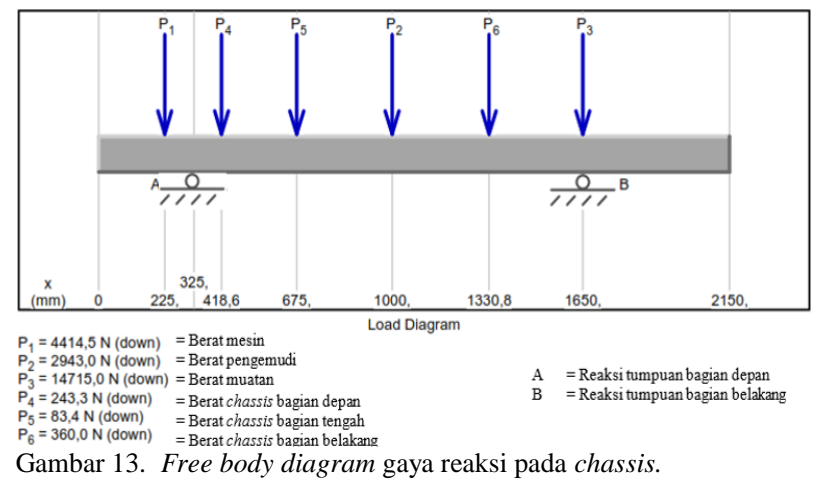

$$
\begin{aligned}
& \sum M_{A}=0 \\
& B=\frac{-P_{1} \times 100+P_{2} \times 675+P_{3} \times 1325+P_{4} \times 93,6+P_{5} \times 350+P_{6} \times 1005,8}{1325} \\
& B=16193,6 \\
& A=6565,6
\end{aligned}
$$

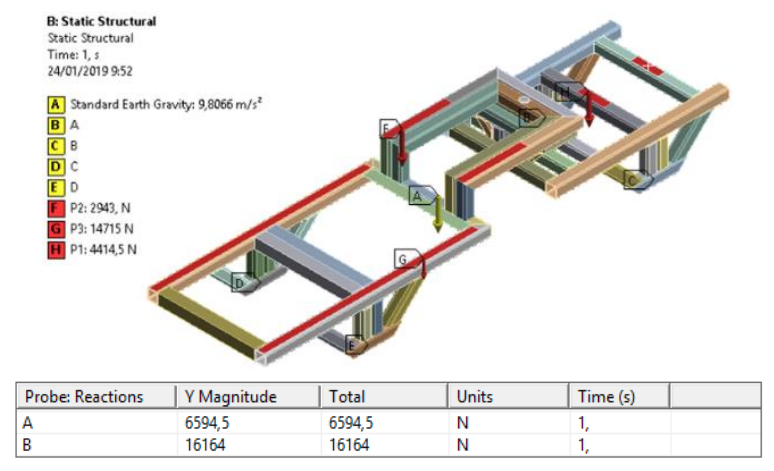

Gambar 14. Gaya reaksi pada chassis.

Tabel 5. Perbandingan gaya reaksi pada chassis.

\begin{tabular}{|c|r|r|}
\hline \multirow{2}{*}{ Bagian } & \multicolumn{2}{|c|}{$\mathrm{F}(\mathrm{N})$} \\
\cline { 2 - 3 } & Manual & \multicolumn{1}{c|}{ Software } \\
\hline A & 6566,6 & 6594,5 \\
\hline B & 16193,6 & 16164,0 \\
\hline & 22760,2 & 22758,5 \\
\cline { 2 - 3 }
\end{tabular}

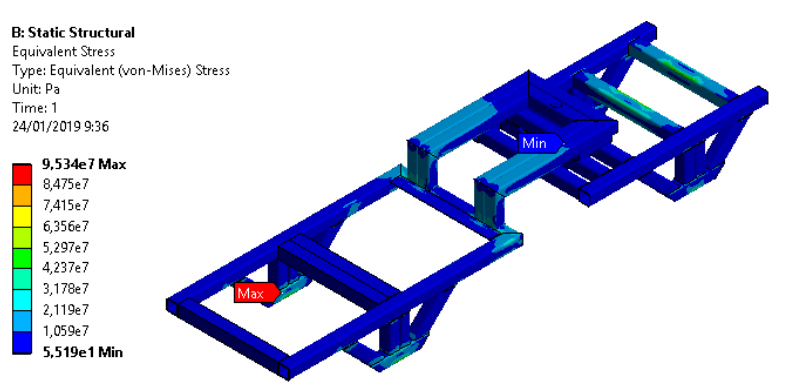

Gambar 15. Hasil simulasi von-Mises stress.

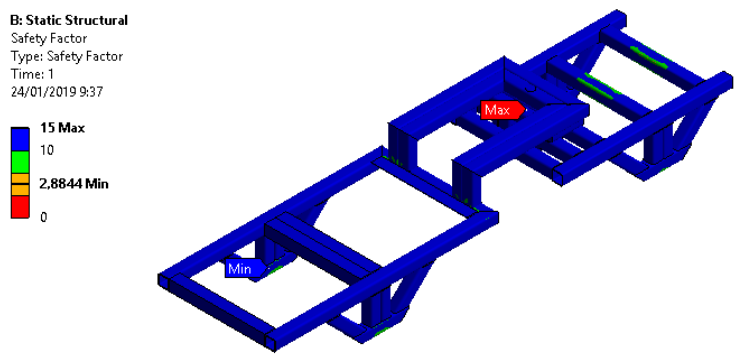

Gambar 16. Hasil simulasi safety factor.

Safety factor minimal yang terjadi pada chassis besarnya 2,8844 yang berarti chassis memenuhi spesifikasi desain yang telah ditentukan yaitu batas minimal untuk safety factor adalah 1,5.

2. Kondisi Bergerak Lurus Dipercepat

Permodelan dikondisikan saat kendaraan bergerak lurus dipercepat dari kondisi diam. Beban yang diterima adalah beban vertikal dan beban akibat gaya inersia. Besarnya gaya inersia dipengaruhi oleh massa chassis, beban beban yang diterima chassis dan percepatan yang dialami.

Percepatan yang berlaku dapat diperoleh dengan perhitungan berikut :

Daya maksimum $(\mathrm{P})=14(\mathrm{HP})=10440($ watt $)$

Kecepatan maksimum $\left(\mathrm{V}_{\mathrm{t}}\right)=25(\mathrm{~km} / \mathrm{h})=6,9(\mathrm{~m} / \mathrm{s})$

Massa total maksimum $(\mathrm{m}) \quad=820(\mathrm{~kg})$

Percepatan yang akan digunakan pada perhitungan gaya inersia berasal dari persamaan daya sebagai berikut [4]:

$\mathrm{P}=\mathrm{F} \cdot \mathrm{V}_{\mathrm{t}}$

$\mathrm{P}=(\mathrm{m} \cdot \mathrm{a}) \cdot \mathrm{V}_{\mathrm{t}}$

$\mathrm{a}=\frac{\mathrm{P}}{\mathrm{m} \cdot \mathrm{V}_{\mathrm{t}}}=\frac{10440}{820 \times 6,9}=1,845\left(\mathrm{~m} / \mathrm{s}^{2}\right)$ 
Gaya inersia dapat dihitung dengan persamaan berikut :

$\mathrm{F}_{\text {inersia }}=\mathrm{m} \cdot \mathrm{a}$

Tabel 6. Momen inersia pada chassis.

\begin{tabular}{|l|r|r|r|r|}
\hline \multicolumn{1}{|c|}{ Beban } & $\mathrm{m}(\mathrm{kg})$ & $\mathrm{t}(\mathrm{mm})$ & $\mathrm{F}_{\mathrm{i}}(\mathrm{N})$ & $\mathrm{M}_{\mathrm{i}}(\mathrm{N}-\mathrm{m})$ \\
\hline Chassis Depan & 24,8 & 167,3 & 45,8 & 7,7 \\
\hline Chassis Tengah & 8,5 & 267,4 & 15,7 & 4,2 \\
\hline Chassis Belakang & 36,7 & 230,8 & 67,7 & 15,6 \\
\hline Mesin & 150,0 & 711,0 & 276,8 & 196,8 \\
\hline Pengemudi & 100,0 & 715,0 & 184,5 & 131,9 \\
\hline Muatan & 500,0 & 800,0 & 922,5 & 738,0 \\
\cline { 5 - 6 } & & & 1512,9 & 1094,2 \\
\cline { 5 - 6 }
\end{tabular}

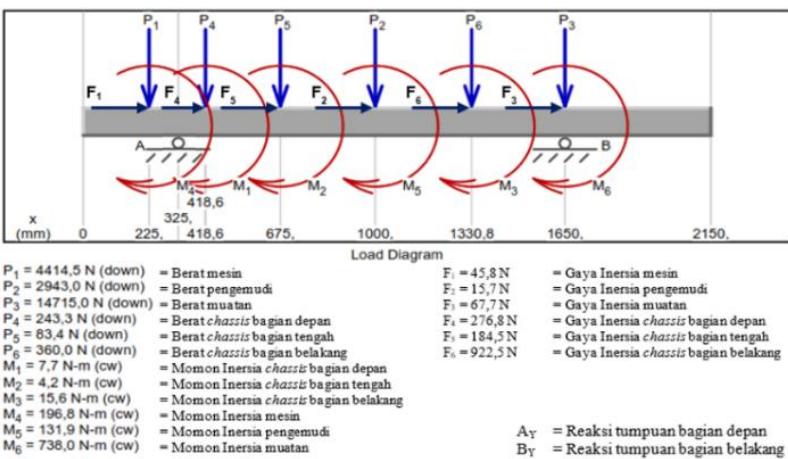

Gambar 17. Free body diagram gaya reaksi pada chassis.

Tabel 7. Momen pada chassis.

\begin{tabular}{|c|c|c|c|}
\hline Beban & $\mathrm{W}(\mathrm{N})$ & $\mathrm{x} \rightarrow \sum \mathrm{M}_{\mathrm{A}}=0$ & $\mathrm{M}(\mathrm{N}-\mathrm{mm})$ \\
\hline Chassis Depan & 243,3 & 93,6 & 22771,8 \\
\hline Chassis Tengah & 83,4 & 350,0 & 29184,8 \\
\hline Chassis Belakang & 360,0 & 1005,8 & 362115,2 \\
\hline Mesin & 4414,5 & $-100,0$ & $-441450,0$ \\
\hline Pengemudi & 2943,0 & 675,0 & 1986525,0 \\
\hline Muatan & 14715,0 & 1325,0 & 19497375,0 \\
\hline Momen Inersia & & & 1094200,0 \\
\hline & & & 22550721,7 \\
\hline
\end{tabular}

$B=\frac{22550721,7}{1325}=17019,4$

$A=5739,8$

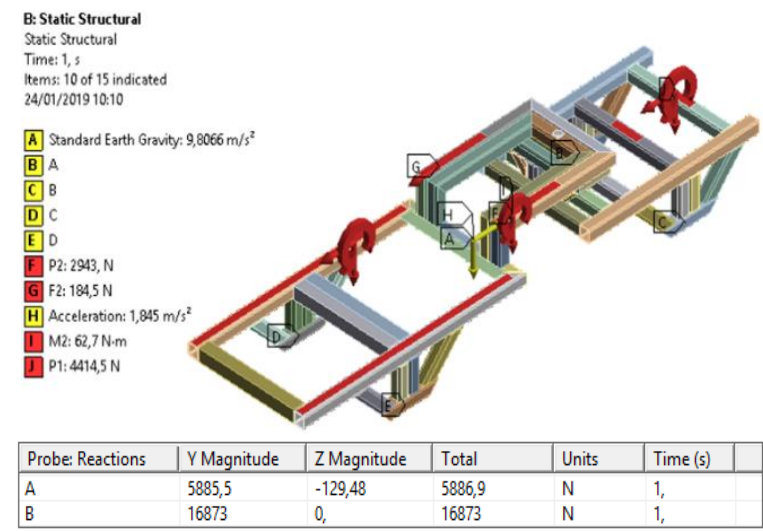

Gambar 18. Gaya reaksi pada chassis.

Tabel 8. Perbandingan gaya reaksi pada chassis.

\begin{tabular}{|c|r|r|}
\hline \multirow{2}{*}{ Bagian } & \multicolumn{2}{|c|}{$\mathrm{F}(\mathrm{N})$} \\
\cline { 2 - 3 } & \multicolumn{1}{|c|}{ Manual } & \multicolumn{1}{c|}{ Software } \\
\hline A & 5739,8 & 5885,5 \\
\hline B & 17019,4 & 16873,0 \\
\hline & 22759,2 & 22758,5 \\
\hline
\end{tabular}

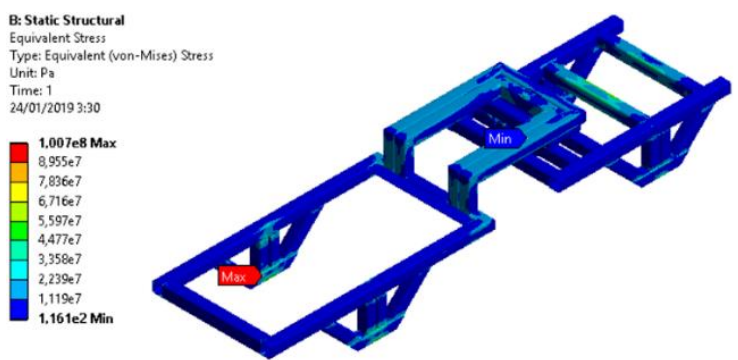

Gambar 19. Hasil simulasi von-Mises stress.

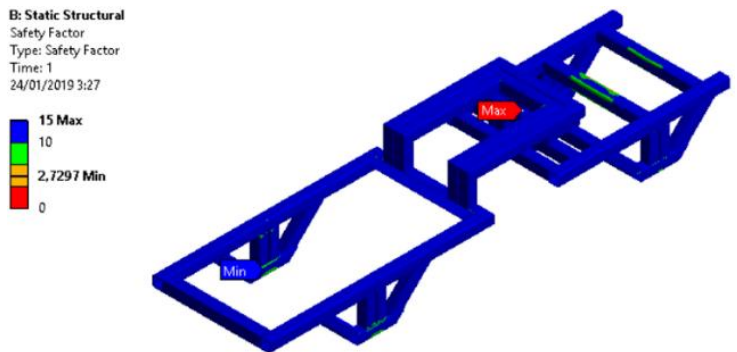

Gambar 20. Hasil simulasi safety factor.

Safety factor minimal yang terjadi pada chassis besarnya 2,7297 yang berarti chassis memenuhi spesifikasi desain yang telah ditentukan yaitu batas minimal untuk safety factor adalah 1,5.

3. Kondisi Bergerak Lurus Diperlambat

Ketika mengalami pengereman chassis menerima beban vertikal dan beban inersia akibat perlambatan. Besarnya perlambatan pada kendaraan didapatkan dari perhitungan berikut :

Kecepatan awal $\left(V_{0}\right)=25 \mathrm{~km} / \mathrm{h}=6,9 \mathrm{~m} / \mathrm{s}$

Jarak sebelum berhenti $(s)=12,33 \mathrm{~m}$

Percepatan yang akan digunakan pada perhitungan gaya inersia berasal dari persamaan daya sebagai berikut [4]:

$V_{t}^{2}=V_{0}^{2}+2 a s$

$$
a=\frac{V_{t}{ }^{2}-V_{0}{ }^{2}}{2 s}=\frac{0-6,9^{2}}{2 \cdot 12,33}=-1,93\left(\mathrm{~m} / \mathrm{s}^{2}\right)
$$

Gaya inersia dapat dihitung dengan persamaan berikut :

$\mathrm{F}_{\text {inersia }}=\mathrm{m} \cdot \mathrm{a}$

Tabel 9. Momen inersia pada chassis.

\begin{tabular}{|l|r|r|r|r|}
\hline \multicolumn{1}{|c|}{ Beban } & $\mathrm{m}(\mathrm{kg})$ & $\mathrm{t}(\mathrm{mm})$ & $\mathrm{F}_{\mathrm{i}}(\mathrm{N})$ & $\mathrm{M}_{\mathrm{i}}(\mathrm{N}-\mathrm{m})$ \\
\hline Chassis Depan & 24,8 & 167,3 & 47,1 & 7,9 \\
\hline Chassis Tengah & 8,5 & 267,4 & 16,2 & 4,3 \\
\hline Chassis Belakang & 36,7 & 230,8 & 69,7 & 16,1 \\
\hline Mesin & 150,0 & 711,0 & 285,0 & 202,6 \\
\hline Pengemudi & 100,0 & 715,0 & 190,0 & 135,9 \\
\hline Muatan & 500,0 & 800,0 & 950,0 & 760,0 \\
\hline
\end{tabular}

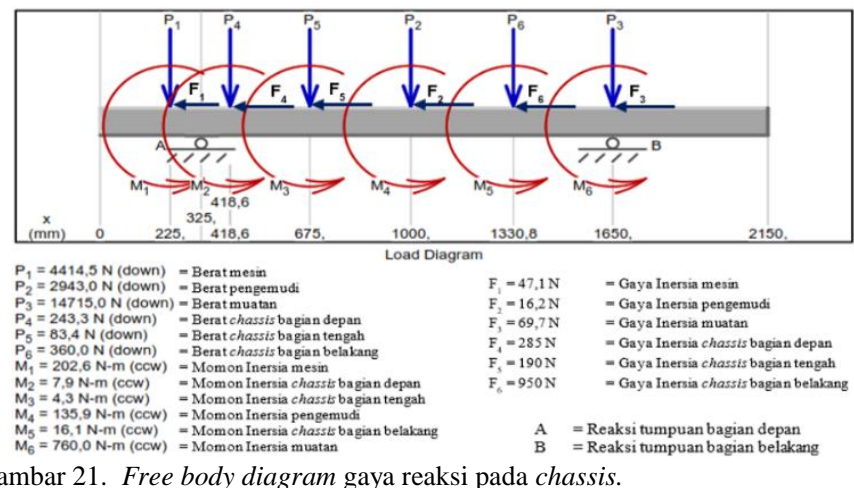


Tabel 10. Momen pada chassis.

\begin{tabular}{|l|r|r|r|}
\hline \multicolumn{1}{|c|}{ Beban } & $\mathrm{W}(\mathrm{N})$ & $\mathrm{x} \rightarrow \sum \mathrm{M}_{\mathrm{A}}=0$ & $\mathrm{M}(\mathrm{N}-\mathrm{mm})$ \\
\hline Chassis Depan & 243,3 & 93,6 & 22771,8 \\
\hline Chassis Tengah & 83,4 & 350,0 & 29184,8 \\
\hline Chassis Belakang & 360,0 & 1005,8 & 362115,2 \\
\hline Mesin \& Transmisi & 4414,5 & $-100,0$ & $-441450,0$ \\
\hline Pengemudi & 2943,0 & 675,0 & 1986525,0 \\
\hline Muatan & 14715,0 & 1325,0 & 19497375,0 \\
\hline Momen Inersia & & & $-1126800,0$ \\
\hline \multicolumn{2}{|r}{} & & 20329721,7 \\
\cline { 2 - 4 }
\end{tabular}

$\sum \mathrm{M}_{\mathrm{A}}=0$

$B=\frac{20329721,7}{1325}=15343,2$

$A=7416$

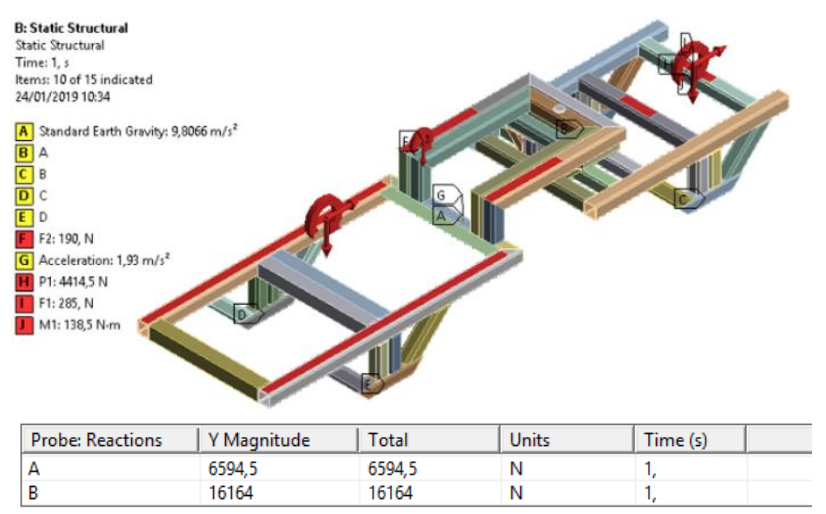

Gambar 22. Gaya reaksi pada chassis.

Tabel 11. Perbandingan gaya reaksi pada chassis.

\begin{tabular}{|c|r|r|}
\hline \multirow{2}{*}{ Bagian } & \multicolumn{2}{|c|}{$\mathrm{F}(\mathrm{N})$} \\
\cline { 2 - 3 } & Manual & \multicolumn{1}{c|}{ Software } \\
\hline A & 7416,0 & 7418,8 \\
\hline B & 15343,2 & 15341,0 \\
\hline & 22759,2 & 22759,8 \\
\hline
\end{tabular}

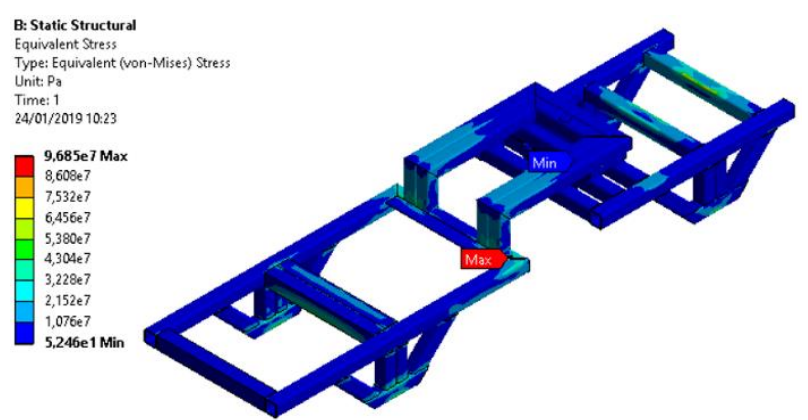

Gambar 23. Hasil simulasi von-Mises stress.

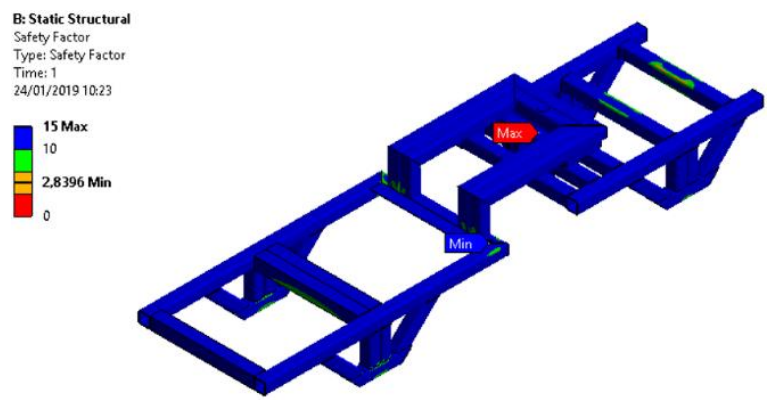

Gambar 24. Hasil simulasi safety factor.

Safety factor minimal yang terjadi pada chassis besarnya 2,8396 yang berarti chassis memenuhi spesifikasi desain yang telah ditentukan yaitu batas minimal untuk safety factor adalah 1,5.

4. Kondisi Belok demgan Kecepatan Konstan

Permodelan keempat akan dikondisikan saat kendaraan bergerak belok dan dengan kecepatan konstan. Beban yang diterima adalah beban vertikal dan beban lateral. Beban akibat gaya lateral arahnya keluar arah radius belok. Gaya lateral dapat dihitung dengan persamaan berikut [4] :

Kecepatan belok $(v)=5 \mathrm{~km} / \mathrm{h}(1,66 \mathrm{~m} / \mathrm{s})$

Radius belok $(R) \quad=1,75 \mathrm{~m}$

$\mathrm{F}_{\text {lateral }}=\mathrm{m} \cdot \mathrm{a}_{\text {sentrifugal }}$

$\mathrm{a}_{\text {sentrifugal }}=\frac{\mathrm{v}^{2}}{\mathrm{R}}$

$\mathrm{a}_{\text {sentrifugal }}=\frac{1,66^{2}}{1,75}=1,55\left(\mathrm{~m} / \mathrm{s}^{2}\right)$

Tabel 12. Momen lateral pada chassis.

\begin{tabular}{|l|r|r|r|r|}
\hline \multicolumn{1}{|c|}{ Beban } & $\mathrm{m}(\mathrm{kg})$ & $\mathrm{t}(\mathrm{mm})$ & $\mathrm{F}_{1}(\mathrm{~N})$ & $\mathrm{M}_{1}(\mathrm{~N}-\mathrm{m})$ \\
\hline Chassis Depan & 24,8 & 167,3 & 38,4 & 6,4 \\
\hline Chassis Tengah & 8,5 & 267,4 & 13,2 & 3,5 \\
\hline Chassis Belakang & 36,7 & 230,8 & 56,9 & 13,1 \\
\hline Mesin & 150,0 & 711,0 & 232,5 & 165,3 \\
\hline Pengemudi & 100,0 & 715,0 & 155,0 & 110,8 \\
\hline Muatan & 500,0 & 800,0 & 775,0 & 620,0 \\
\hline
\end{tabular}

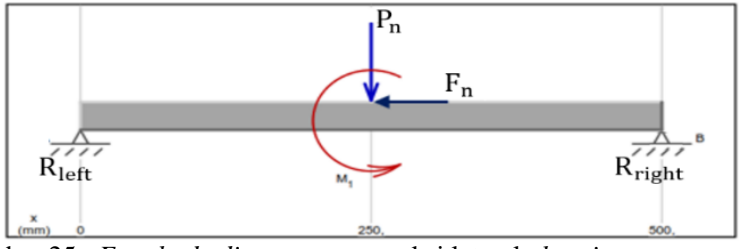

Gambar 25. Free body diagram gaya reaksi lateral chassis.

$\sum \mathrm{M}_{\mathrm{A}}=0$

$\mathrm{R}_{\text {right }_{n}}=\frac{\mathrm{W}_{\mathrm{n}} \times 0,25+\mathrm{M}_{\mathrm{I}_{\mathrm{n}}}}{0,5}$

$\mathrm{R}_{\text {left }_{n}}=\mathrm{W}_{\mathrm{n}}-\mathrm{R}_{\text {right }_{n}}$

Tabel 13. Momen pada chassis.

\begin{tabular}{|l|r|r|r|r|r|}
\multicolumn{7}{|c}{ Tabel 13. Momen pada chassis. } \\
\hline \multicolumn{1}{|c|}{ Beban } & $\mathrm{W}(\mathrm{N})$ & $\mathrm{M}_{\mathrm{l}}(\mathrm{N}-\mathrm{m})$ & $\mathrm{x} \rightarrow \sum \mathrm{M}_{\mathrm{A}}=0$ & Right $(\mathrm{N})$ & Left $(\mathrm{N})$ \\
\hline Chassis Depan & 243,3 & 6,4 & 250,0 & 134,5 & 108,8 \\
\hline Chassis Tengah & 83,4 & 3,5 & 250,0 & 48,7 & 34,6 \\
\hline Chassis Belakang & 360,0 & 13,1 & 250,0 & 206,3 & 153,8 \\
\hline Mesin & 4414,5 & 165,3 & 250,0 & 2537,9 & 1876,6 \\
\hline Pengemudi & 2943,0 & 110,8 & 250,0 & 1693,2 & 1249,9 \\
\hline Muatan & 14715,0 & 620,0 & 250,0 & 8597,5 & 6117,5 \\
\hline
\end{tabular}

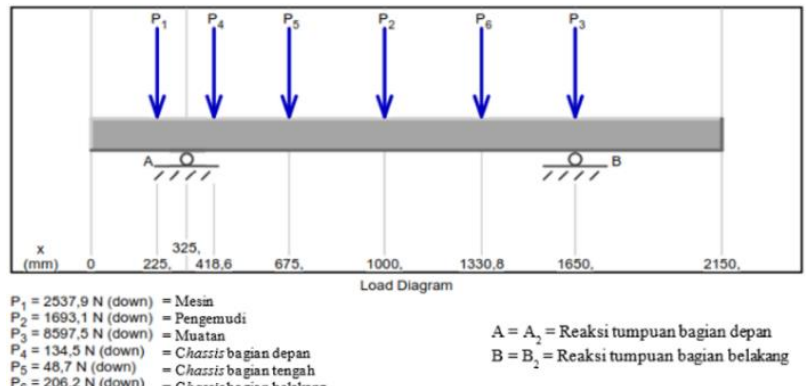

Gambar 26. Free body diagram gaya reaksi right chassis. 
$\sum \mathrm{M}_{\mathrm{A}}=0$

$\mathrm{B}=\frac{-\mathrm{P}_{1} \times 100+\mathrm{P}_{2} \times 675+\mathrm{P}_{3} \times 1325+\mathrm{P}_{4} \times 93,6+\mathrm{P}_{5} \times 350+\mathrm{P}_{6} \times 1005,8}{1325}$
$\mathrm{~B}=9.447,36$
$\mathrm{~A}=3,770,52$

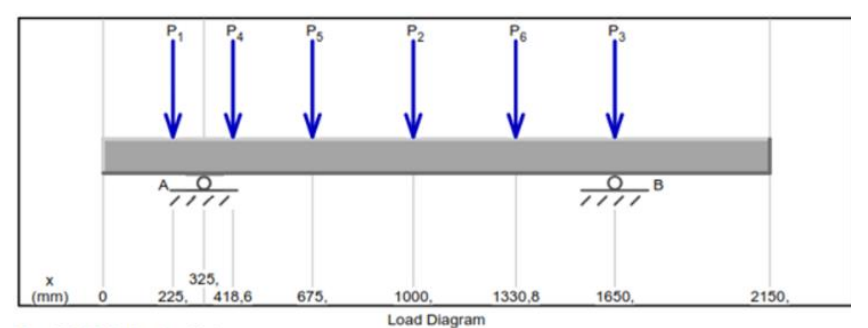

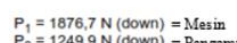

$P_{2}=1249.9 \mathrm{~N}$ (down) $=$ Pengemu
$P_{3}=6117,5 \mathrm{~N}$ (down) $=$ Nuatan $P_{4}=108,8 \mathrm{~N}$ (down) $=$ Chassis bagian depan $P_{5}=34,7 \mathrm{~N}$ (down) $\quad=$ Chassis bagian tengah
$P_{6}=153,8 \mathrm{~N}$ (down) $\quad=$ Chassis bagian belakang

Gambar 27. Free body diagram gaya reaksi left chassis.

$\sum \mathrm{M}_{\mathrm{A}}=0$

$\mathrm{B}=\frac{-\mathrm{P}_{1} \times 100+\mathrm{P}_{2} \times 675+\mathrm{P}_{3} \times 1325+\mathrm{P}_{4} \times 93,6+\mathrm{P}_{5} \times 350+\mathrm{P}_{6} \times 1005,8}{1325}$

$\mathrm{B}=6.746,21$

$\mathrm{A}=2.795,19$

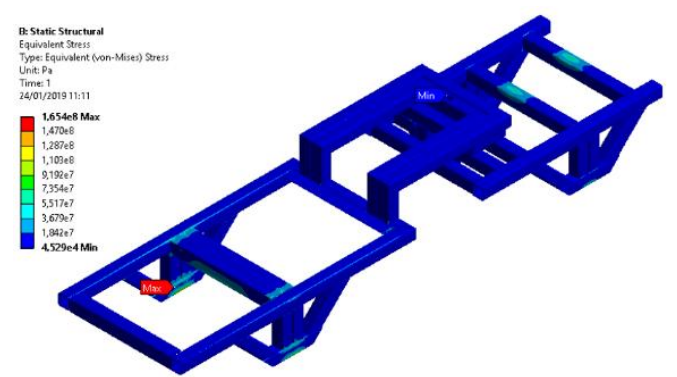

Gambar 28. Hasil simulasi von-Mises stress.

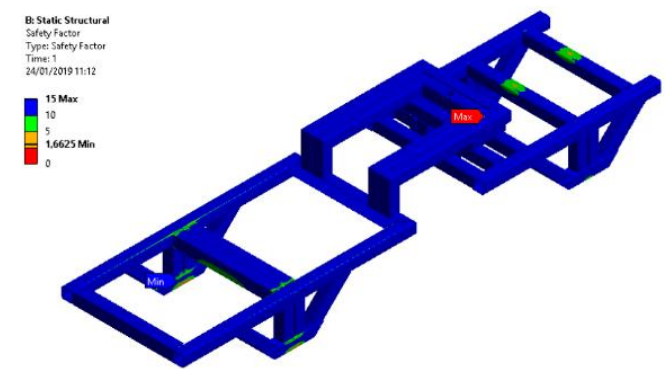

Gambar 29. Hasil simulasi safety factor.
Safety factor minimal yang terjadi pada chassis besarnya 1,6625 yang berarti chassis memenuhi spesifikasi desain yang telah ditentukan yaitu batas minimal untuk safety factor adalah 1,5.

\section{KESIMPULAN}

Berdasarkan hasil dan pembahasan yang telah dilakukan dapat diambil kesimpulan yang dapat menjawab tujuan dari penelitian ini sebagai berikut :

1. Nilai maksimum von-Mises stress terbesar chassis ada pada kondisi belok yaitu sebesar 165,4 MPa.

2. Nilai maksimum von-Mises stress terkecil chassis ada pada kondisi kecepatan konstan yaitu sebesar 95,3 MPa.

3. Nilai minimum safety factor terkecil chassis ada pada kondisi belok yaitu sebesar 1,66.

4. Nilai minimum safety factor terbesar chassis ada pada kondisi kecepatan konstan yaitu sebesar 2,88.

5. Desain chassis yang di rancang telah berhasil memenuhi spesifikasi desain :

a. Safety factor minimal lebih dari 1,5 sehingga desain chassis bisa dinyatakan cukup aman.

b. Desain chassis yang di rancang telah berhasil memenuhi spesifikasi dimensi yaitu panjang $2150 \mathrm{~mm}$ dan lebar $550 \mathrm{~mm}$.

c. Roda depan sebagai penggerak serta penentu arah belok dengan model chassis articulated frame.

d. Radius belok kecil yaitu $1704 \mathrm{~mm}$.

\section{DAFTAR PUSTAKA}

[1] F. Rahim and B. Ariatedja, "Perancangan dan Analisa Sistem Transmisi Infrastructural Mobile dari Hasil Pertanian," Surabaya, 2018.

[2] Y. Yin, "Design optimization of an articulated frame steering system Proceedings of the Institution of Mechanical Engineers," J. Automob. Eng., vol. D, no. 10.1, 2017.

[3] J. Brown and A. Robertson, "Motor Vehicle Structures: Concepts and Fundamentals."

[4] A. Wiratama, "Analisa Kekuatan Chassis Bus Listrik menggunakan Simulasi Berbasis Metode Elemen Hingga," Surabaya, 2015. 